\title{
Téoros
}

Revue de recherche en tourisme

\section{Festivals, Migration, and Long-term Residency}

\section{David L. Groves et Dallen Timothy}

Volume 20, numéro 1, printemps 2001

URI : https://id.erudit.org/iderudit/1071912ar

DOI : https://doi.org/10.7202/1071912ar

Aller au sommaire du numéro

Éditeur(s)

Université du Québec à Montréal

ISSN

0712-8657 (imprimé)

1923-2705 (numérique)

Découvrir la revue

Citer cet article

Groves, D. L. \& Timothy, D. (2001). Festivals, Migration, and Long-term

Residency. Téoros, 20(1), 56-62. https://doi.org/10.7202/1071912ar d'utilisation que vous pouvez consulter en ligne.

https://apropos.erudit.org/fr/usagers/politique-dutilisation/ 


\section{Festivals, Migration, and Long-ferm Residency ${ }^{1}$}

\section{David L. Groves and Dallen Timothy}

Les festivals constituent un important apport au développement des produits touristiques. Certaines études ont exploré les conséquences économiques des festivals; pew, en revanche, ont examine leur effet à long terme sur la communauté hôte. Les effets résiduels des festivals ne sont pourtant pas négligeables, notamment au regard du de veloppement de relations * durables s entre les visiteurs et l'espace visité. Plus encoré, une analyse de ces relations permetrait d'envisager le développement a long terme d'un second cycle de produits.

\section{Introduction}

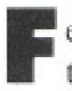
estivals are one of the most common types of tourism activities in destination communities. They range in size from small, local affairs, to mega-events like World Fairs and Olympics. The common element in each of these is a celebration at a given time (Carpenter, 1995). Thus, they are perishable, as the same conditions in time will never exist again. According to one estimate, one-fifth of all tourism is directly or indirectly linked to festivals (Anonymous, 1999). Festivals have been studied from a number of different perspectives as a tourism product. One of the most interesting angles is their study as a life cycle (Walle, 1994; Yu and Van Arsdol, 1977), that is with a beginning, a growth period, a leveling-off, and a decline at some phase as well as a potential renewal period. Even though that is a common process, each festival has a distinct life cycle. Understanding the elements that influence their development is vital to understanding the nature and characteristics of festivals (Farber, 1983). Even though that perspective is unique, from a systems perspective, the data must be reviewed in relation to the tourism products and the development of the impacts that a festival has in the longterm (Crompton and McKay, 1997; Rodriguez, 1998). For example, it is common for individuals who vacation in a specific area, to develop a personal attachment to the destination and, when they retire, to become seasonal *snowbirds or permanent residents of their vacation place (Marshall and Longino, 1990). Thus, a broader systems approach may yield a great deal of information for understanding the basic development of the tourism product in relation to permanent residency (Crompton and Love, 1995; Dawson, 1991). These types of relationships suggest a very simple connection between tourism and residency, when, in fact, it seems to be a very complex phenomenon that has been given seant research attention in recent years (Goodrich, 1978). It is important to understand the evolutionary process in relation to the demand curves for each development phase of a festival.

\section{Settling reasons}

Another phenomenon that could suggest the complexity of these relationships is the sister cities program, whether between domestic cities or between cities in different countries. The nature of these relationships is highly complex and their impacts potentially widespread (Rothman, 1978). Cross-cultural theories (and cultural analysis concerned with the symbiotic relations and their reciprocal impacts) help explain that type of phenomenon and the impacts and relationships that have developed (Cantwell, 1991; St-Onge, 1991): the primary concern is the developmental process as it relates to normative as well as personal relations and their interactions. Tourism (as traveling for recreation) is a natural element in cross-cultural impacts because of the host-guest interactions. That condition forces interaction and sometimes the development of new relationships between hosts and guests. Environmental (social) conditions-eventually leading to familiarity, which affects acculturationseem to be the primary element in the initial developmental process. Secondary development is the result of the primary elements and the nature of the cultural differences between hosts and guests. 
There is little doubt that one community has an impact on another economically, socially, and culturally (Timothy, 1995).

For years scholars have attempted to understand why traditional migrants (not tourists) settle in certain regions. One early theory suggested that migrants settled where the local environment reminded them of the homeland (Semple, 1903; van Cleef, 1918). That deterministic view of traditional migration patterns has since been disputed and other more rational reasons have been suggested. Since the primary factor for the location of most traditional migrant groups was employment, many groups ended up in locations that rescmbled their home environments, but that was usually a result of coincidence, not choice, owing to the types of labor they were pursuing. As for tourism-related migration, familiarity seems an important condition.

In fact, another reason for continued traditional migration in certain regions, often subsequent to employment, was social networks-people of a distinct culture began to create communities. As previously mentioned, social islands tend to act as magnets to others with the same background. Generally speaking, the migrants. who followed later were usually aware of the community's existence before they relocated, and it became their destination of choice. Original enclave pioneers often recruit others of the same background and typically provide help to newcomers (Abrahamson, 1996). Tourism migration is also influenced by social networks, but is not as well-formed/structured; the network is rather a community of support than a community of location and identity.

\section{Tourism migration in the Southern States}

Following World War II, as the economy of Florida and other southern states became stronger and more diversified, tourism began to develop rapidly. In response to that and other factors, more people than ever before from the northem United States began traveling south for the winter. That influx of seasonal tourists included some financially self-sufficient tourists who could afford to spend the winter months in the South.
Upon learning of the tourism boom in Florida and other southern states, many tourists, especially seniors, traveled there for the winter in search of a warmer climate and friendly surroundings. Consequently, family and friends began to visit and settle in these southern areas. By the 1950 s, it had become more common for northerners to spend their winters in the southern climates.

That led to a significant watve of "retired tourists" moving permanently from the north to the communities of the south in the 1940s and 50s (Stoller, 1989). In accordance with the general patterns associated with retiree migration (Cuba, 1989; Krout, 1983: McHugh, 1990), most permanent residents had spent winter holidays in the region prior to retiring and settling there.

Permanent tesidents today primarily include first- and second-generation retirees from the north, although since the 1960 s there has been a significant influx of immigration. The large community of older tourists has attracted younger compatriots who provide goods and services to the retirees. Many of these are secondand third-generation northerners (Stoller, 1998 : 289). Recent years have seen a more rapid influx of younger tourists who visit an area, usually because of family, and end up becoming permanent residents. Good

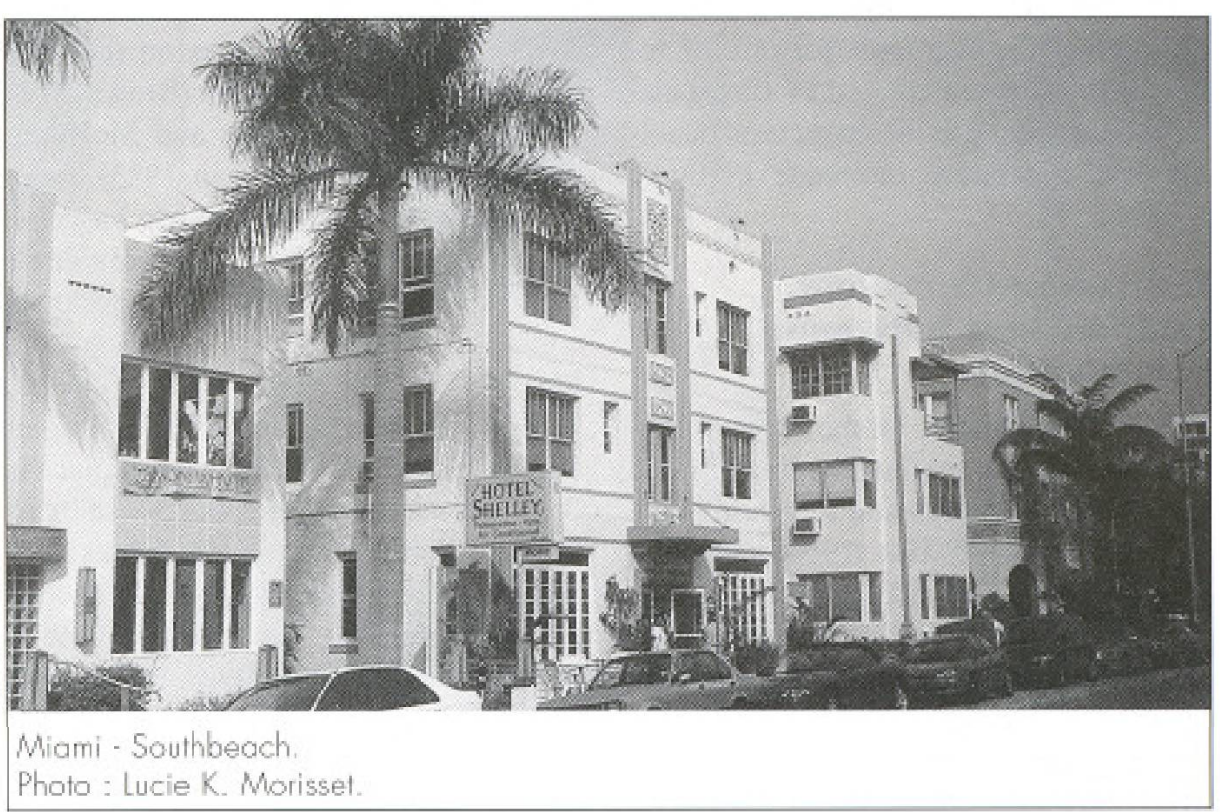

jobs are available in service industries and construction, and communities are strong.

Three types of "tourists" can be identified in the area. Members of the first group are in fact not tourists at all, although they originally were. These are the first-, second-, and third-generation tourists, as well as the more recent migrants directly from the north, who have made the south their permanent home. Most people in that category have a permanent resident status. The second group is comprised of those who live in the North most of the year but spend the winter months in the South. These people spend the spring, summer, and fall in the north but make their way southward in December or January, and stay until March or April. Several own businesses that are opened only during the winter season to cater to the wider tourist market. Finally, the third type of tourists is the short-term winter vacationer. That group typically stays from one to four weeks and often includes families with young children.

While most people in the first wave of tourists own their homes, many of the seasonal and short-term visitors do likewise $^{2}$. It is common for a family to own a townhouse (or, in some cases, two) for their own use during their one- or twoweek annual trips-in fact, several condominium and townhouse complexes are 


\begin{tabular}{|c|c|c|}
\hline \multicolumn{3}{|c|}{$\begin{array}{l}\text { TABIE I } \\
\text { Dovelogmantal lsanes }\end{array}$} \\
\hline RELATIONSHIPS & CONDITIONS & IMPORTANT VARIABLES OR CAUSE \\
\hline $\begin{array}{l}\text { 1. Low economir impact and understand reosons } \\
\text { why individuels visit an area }\end{array}$ & 1. Business starts to develop in a community & 1. Location/dimate, worm weather \\
\hline $\begin{array}{l}\text { 2. Explonatory discussions io make others realize the } \\
\text { impertanee of the noture of the tourism potential }\end{array}$ & 2. Business community realizes the nafure and polential of economit impoct & 2. Foresight for potential business \\
\hline $\begin{array}{l}\text { 3. Understanding the polenlial and what is needed } \\
\text { to atirat target audiente to community }\end{array}$ & $\begin{array}{l}\text { 3. Business community presents promotions to community leoders and discuss } \\
\text { potential impocts, especially economit, on communily }\end{array}$ & $\begin{array}{l}\text { 3. The extent of the business community leodership } \\
\text { in influenting the bronder community, especially } \\
\text { politicions }\end{array}$ \\
\hline $\begin{array}{l}\text { 4. Explaring geogrophic areos where inifial business } \\
\text { comes from and potential of other similar areas }\end{array}$ & 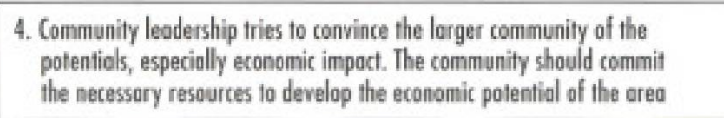 & $\begin{array}{l}\text { 4. The impact of the political community as a leader } \\
\text { in influencing the larger community }\end{array}$ \\
\hline $\begin{array}{l}\text { 5. Understanding the culture and how to devalop } \\
\text { incentives to attract lourists }\end{array}$ & $\begin{array}{l}\text { 5. Development af professional tourism relationships and business to business } \\
\text { relationships for the development of a strategic plan }\end{array}$ & $\begin{array}{l}\text { 5. Positive cultural perspective that wants and } \\
\text { understands international visitors }\end{array}$ \\
\hline 6. Business to vistors relationships & $\begin{array}{l}\text { 6. Davalopment of promotions for spring when business needs coincide } \\
\text { with academic spring break }\end{array}$ & $\begin{array}{l}\text { 6. Ability to persunde international vititors to come } \\
\text { to area; uniqueness = warm wenther }\end{array}$ \\
\hline $\begin{array}{l}\text { 7. Development of o friendly onvironment } \\
\text { for attendance, especially using previous visitors }\end{array}$ & 7. Organization of o festival to develop international relationships & $\begin{array}{l}\text { 7. Ability to market and promote event; ability to } \\
\text { initiate an event and make it successful }\end{array}$ \\
\hline $\begin{array}{l}\text { 8. Ability io develop friendly, international reletionships; } \\
\text { moke international visitors feel at home }\end{array}$ & 8. Popularize and develop the festivel; grouth period & $\begin{array}{l}\text { 8. Event manogement skills with internationel } \\
\text { perspective }\end{array}$ \\
\hline $\begin{array}{l}\text { 9. Develop sister city relationships; develop relationships } \\
\text { with local visitors and with sthool systems }\end{array}$ & 9. Sustain event and increase papularity & $\begin{array}{l}\text { 9. Ability to create environment for denelopment/ } \\
\text { money exchange at por }\end{array}$ \\
\hline 10. Development of individual to individual relationships & $\begin{array}{l}\text { 10. Event achisves popularily; signifitani etonomic import; } \\
\text { more Canadian wacations }\end{array}$ & 10. Ability to creale new business opportunifies \\
\hline $\begin{array}{l}\text { 11. Conadian winter and permanent residency: } \\
\text { same Canadians invest in Myrile businesses }\end{array}$ & 11. Event moturity; ather spring besinesses overshadow Con. Am. Dows & $\begin{array}{l}\text { 11. Ability to serve international dients on a } \\
\text { year-round bosis }\end{array}$ \\
\hline 12. Lock of interest and doing just enough to keep going & $\begin{array}{l}\text { 12. No need for event's economic development, but is noe o tradition; } \\
\text { odditional focus on oiher international events and visitiors }\end{array}$ & 12. Loss of leadership \\
\hline
\end{tabular}

vacant for a fifty-week period each year. Most of the locations of the developed communities in an area are related to rapid and convenient accessibility. These special migratory patterns may be called "flightways," geographic patterns of accessibility that are created by travel and have been related to infrastructural development, especially interstate highway access.

\section{Tourism products and relationships between communities}

The primary literature for the interpretation of data concerns studies that focus on the snowbirding process and migration patterns (Cuba, 1989; Hitt, 1954; Long and Perdue, 1990; Krout, 1983; Jobes, 1984; Martin et al., 1987; Sullivan and Stevens, 1982). Many of these studies try to isolate the economic impact of that phenomenon on geographic regions (Graham, 1998). They indicate that the economic impact is substantial as the population has money to spend, and it is the nature of that experience to be social and involved in group outings (Long and Perdue, 1990; Jordan, 1980; Rose and Kingma, 1989; Zelinsky, 1983). Other studies focus on the geographic origins of the visitor (Brown et al., 1963; Hitt, 1954; Mings and McHugh, 1995; Plane, 1992; Roseman, 1983). There are definite movement patterns, based on their starting point and how individuals from a certain community have developed enclaves (Hoyt, 1954; Longino and Marshall, 1990: Mullins and Tuckers, 1988; Wilson and Martin, 1982; Zeigler and Brunn, 1985). Familiarity of place is the primary factor driving these trips (Ming, 1984). The original variables studied were the highway system and ease of access (McHugh and Gober, 1992; McHugh and Mings, 1992). There have been few studies based on residential development, or on business development that have followed the snowbirding model
(McHugh and Mings, 1992); but these suggest that snowbirding is a condition of permanent residency (Behr and Gober, 1982; Hogan and Steinnes, 1993; McHugh, 1990). There has been very little investigation of a comprehensive model to understand the relationships between tourist at traction and long-term relationships with an area (Wiseman and Roseman, 1979).

A systems approach would help develop a typology to understand the complex relationships between the tourism product-festivals or other attractions-and how relationships develop between communities, and what ultimately has an impact on these relationships (Getz, 1991; Getz and Frisby, 1991). The ultimate objective in understanding these types of relationships is to help communities in the planning of festivals that may determine and influence the long-term residual relationships (Getz and Frisby, 1991; Mayfield and Crompton, 1995). Residual development is one of the 
least explored areas of tourism. In megaevents like World Fairs and Olympics, the residual development has been one of the primary objectives of the event or festival. The obvious relationship that is often explored is between mega-event attendance and whether or not people return for vacation or business given the fact that they have received exposure to that area (Mings, 1984). Economic impacts and returns on investments for holding a special event like a World Fair or Olympics drive these types of questions. When the economic elements are at stake, the short-term effects tend to be the only consideration. The external business it generates and the improvement of the location image are only secondary to the impacts that it has on the community such as increased self-confidence for being able to hold such an event. Likewise, the facilities built for special events have a significant residual impact on the quality of life within that community.

The purpose of this study is to describe a line of research that will result in the development of a typology to understand the relationships between festivals and other tourism events/products in places and the long-term or permanent migration of people who have previously vacationed.

\section{Methodology}

A methodology that has been used quite satisfactorily in the study of festivals/life cycles is folklore analysis (Azuonye, 1990; Hala, 1992; McClenon, 1992). The primary focus of that method is to identify behavioral patterns and to see whether and to what extent these patterns are consistent with their evolution and development (Ben-Amos, 1993; Lareau, 1983; Yangzhou and Ritchie, 1993). The purpose of using folklore analysis in this study was to examine the oral and written traditions that exist as an indicator of the development of short-and long-term relationships of the impacts of festivals on the host and guest relationships (Getz and Frisby, 1988).

This case study focuses on the Can-American Days Festival, which has been held each spring for the past thirty-eight years in Myrtle Beach, South Carolina. The CanAm Festival was chosen because it is one

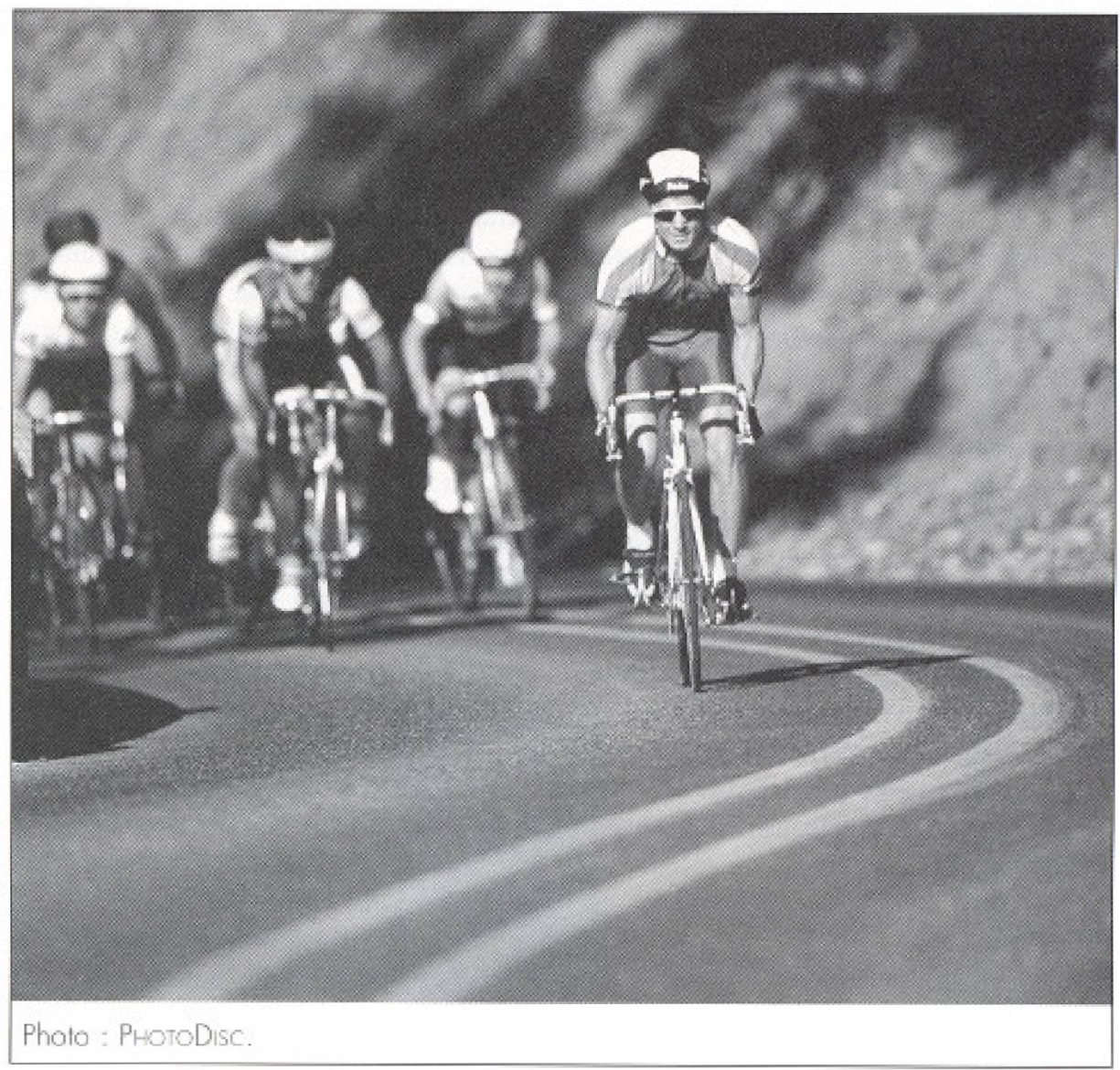

of the most notable international festivals in North America and it involves significant tourism development. Patterns can be identified because that festival has a thirtyeight-year lineage (Mayfield and Crompton, 1995b; Rose and Kingma, 1989). The festival is usually held in March and coincides with school spring breaks, especially in the area of origin of primary concern in this paper-Ontario, Canada. That festival is an important tourism product for Canadian vacationers. The primary audience targeted by Can-Am Days organizers is families. The questions being raised concern the relationships (interactive connection among the actors in the system) that have developed and the order in which they developed (Burgess et al, 1955; Tucker et al, 1988). The purpose of the project is to establish the evolutionary nature of that festival as it has influenced the long=term relationships between Canadians and Americans in Myrtle Beach (Butler, 1980; Shultis et al, 1996). Oral histories were taken from business proprietors as well as other lo- cal individuals who share history with the festival. Additionally, fifteen interviews were completed with community and business leaders, snowbirds, and festivalgoers. These individuals were asked to reflect on the festival and define the important relationships, historical development, and the primary factors that influ= enced the development of the festival. The primary element here was time with the festival in order to understand the longterm relationships. Data relative to attendance patterns and the order of their presence were also collected.

In addition to the folklore analysis, a content thematic analysis was completed of newspaper articles over the last thirtyeight years, in order to gather information on the nature of the event and its development. Primary newspaper articles were reviewed as well as editorial pages to gain some kind of understanding from a temporal linear perspective. The newspaper reviewed was the Myrtle Beach daily newspaper, The Sun News. A thematic 
content analysis was used to study the adaptation/adjustment issues that influence the strategies (Turley and Kelley, 1997; Wheelan and Abraham, 1993; Ramaprasad and Hasegawa, 1992).

A Thurstonian system of judgment was used, wherein common judging among content experts is used to develop a consensus. The content experts were individuals who had knowledge of the travel industry, especially festivals and residency issues. Two dyads were used to judge the material and develop a classification that would characterize the data. Each content expert read the materials and developed a system of transcribing or summarizing it. Then, each judge worked in dyads to come to a consensus on what the article was saying. Classifications or nominal categories were then developed to describe, on a comparative basis, all the data that were analyzed.

\section{Results}

\section{Developmental Issues}

Results suggest that migration theory may be one of the best ways to explain relationships, especially in the long term. It seems that the basic concept is that an identifiable cohort of individuals develops a relationship with an area, more and more people come to that area, and then some type of enclave begins to develop where a process of sub-cultural development begins to occur (see Table 1). That cultural development appears to be related to familiarity and familiar symbols that make

\begin{tabular}{|c|c|c|c|c|c|c|}
\hline \multicolumn{7}{|c|}{ 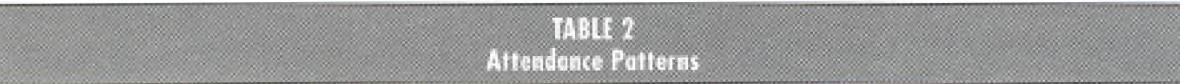 } \\
\hline \multicolumn{7}{|c|}{ FIRST CONTACT / SEQUENCE OF TOURIST EVENTS } \\
\hline I. Festival & $\rightarrow$ & Tourist & $\rightarrow$ & Snowbird & $\rightarrow$ & Resident \\
\hline II. Tourist & $\rightarrow$ & Festival & $\rightarrow$ & Tourist & & \\
\hline III. Snowbird & $\rightarrow$ & Festival & & & & \\
\hline IV. Snowbirt & $\rightarrow$ & Resident & & & & \\
\hline V. Tourist & $\rightarrow$ & Resideat & & & & \\
\hline VI. Festival & $\rightarrow$ & Resident & & & & \\
\hline \multicolumn{7}{|l|}{ VII. Resident } \\
\hline \multicolumn{7}{|l|}{ VIII. Festival } \\
\hline IX. Snowbird & & & & & & \\
\hline
\end{tabular}

the individuals feel at home in the enclave. Individuals in the enclave really develop the sub-cultural threads. Location seems to have little to do with the process, except that some event or attraction initially attracted those who originally settled an area. The primary processes that seems to be working in this case are that of identity as well as friendship. Each of these enclaves has a cultural identity with its own mores and patterns that do not allow other sub-cultures to infringe upon this identity process.

In the case of that particular festival, the originators wanted to start and develop relationships with Canada as a tourism product. The approach taken by the festival planners was to make Canadians who attend the festival feel at home. For example, during the week Canadian news are reported and many businesses accept Canadian currency at par. It is believed that these measures will make Canadians feel at home away from home. Repeat visitation to the festival is apparently quite high and related to the fact that Canadians can drive to Myrtle Beach in only one day to access good weather instead of taking an extra day to reach Florida. Other developmental factors are the special events specifically designed for Canadians during the week. What has developed is a tradition that many of the families in second and third generations come to the Canadian-American Festival. That does not suggest that they come every year, but that they will at least make periodic visits primarily because of the family tradition of visiting the area and the event. There also appears to be a close relationship between the festival and additional visits in the summer.

\section{Attendance Patterns}

The American business community seems to have learned the cultural idiosyncrasies of the Canadians and how to do business with them (see Table 2). Obviously, the economic impact exists because these are when businesses are off-season and the additional business increases occupancy. Relationships have developed far beyond that economic impact. That is a benefit to Canadians based on the price, as well as the increased occupancy for the businesses in Myrtle Beach. There are individuals who "snowbird" in Myrtle Beach from Canada, and they have been festival attendees as well as vacationers. The primary attraction does not necessarily seem to be the enclave concept as much as it is the price and cost of lodging and food. Another element that appears extremely important is that of proximity; the ability to get home rapidly, if need be. There is also a group of "snowbirds" who have never been to the festival or vacationed in Myrtle Beach, but who are social friends with the other individuals who have been to the festival and have vacationed there. That represents the social side of migration. There is more "snowbirding" by Canadians than permanent residency in Myrtle Beach. When there is residency, there is usually an intermediate step of owning a vacation home or time-share unit that gives the sense of residency and residual effect, or long-term relationship. There does seem to be a few Canadians who have permanently settled in Myrtle Beach but they do not choose to use the word enclave; they rather use the word "village." That residency gives families a place to visit and spend vacation time. For permanent residency, the draw does not seem to be time and/or price. These individuals, through repeated contact, have developed a favorite status with the area, have bonded with the local culture, and have made it their home. Permanent residency has the same social relationship as the "snowbirds." Many individuals have migrated to Myrtle Beach because of friends and family. These people have had 
very few previous relationships with the area but have heard about it and have, as a result, moved there to be part of a social group, especially during their retirement years. Eighty-five percent of the Canadian visitors were enticed to visit or establish temporary or long-term residence directly or indirectly because of the Can-American Festival.

\section{Conclusion}

It would seem that migration theory has significant application to the establishment of long-term relationships between festivals and tourism products and beneficial outcomes to both the host and the guest relationships. The secondary benefit that seems to arise is that satisfied customers, through word of mouth, spread the word about Myrtle Beach and then other individuals come and visit based on the recommendation of family and friends. This has a multiplying effect. As a result of that type of relationship, Myrtle Beach has become one of the favorite destinations of Canadian vacationers and the recommendations from the festival are one of the major underlying elements.

In no way should this case study be construed as a model to make generalizations about long-term or residual impacts of festivals and as a tourism product. It may be the beginning of a line of research that may better help understand residuals and their impact and the types of relationships that developed as well as the reason why they have developed. This type of information is essential in long-term planning for communities that have these types of festivals. Most of the positive outcomes of the Can-Am days in Myrtle Beach have been the result of random chance and the development of trial and error processes over the years. It is important that these processes be understood so that there can be products developed that are more scientific and do not depend on a lineage of trial and error processes.

David Groves is Professor in the Division of Spon Management, Recreation, and Tourism, Bowling Green State University.
Dallen Timothy is Assistant Professor in the Department of Recreation Management and Tourism of the Arizona State University.

\section{Notes}

1 Made possible with support from the Canadian Studies Center at Bowling Green State University,

2 Many short-term tourists, however, do not visit Florida and southern areas cvery year, and the majority stays in hotels or rented townhouses.

\section{References}

Abrahamson, M. (1996), Urban Enclaves: Identity and Place in America. New York. St. Martin's Press.

Anonymous (1999), * Vital Signs *, Leisure Travel News, 6.

Azuonye, C. (1990), * Morphology of the Igbo Folktale: Ethnographic, Historiographic and Aesthetic Implications *, Folklore, 10! (1). p 36-46.

Behr, M., and P. Gober, (1982), * When a Residence Is Not a Homc: Examining Residence-Based Migration Definitions \&, Professional Geographer, 34, p. 178-184.

Ben-Amos, D. (1993), w Context" in Context $\%$ Western Folklore, 52 (2-4), p. 209-226.

Brown, J. S., H. K. Sehwarzweller, and J. J. Mangalam (1963), * Kentucky Mountain Migration and the Stem-Family: An American Variation on a Theme by LePlay $\%$, Rural Sociology, 28, p. 48-69.

Burgess, E. W. G. C. Hoyt, and C. R. Manley (1955), The Construction of Scales for the Measurement of Migration After Retirement », Soclomerry, 18, p. 616-623

Butler, R. (1980), * The Concept of a Tourist Arca Cycle of Evolution: Implications for Management of Resources $\%$, Canadian Geographer, 24 (1), p. 5-12.

Cantwell, R. (1991), * Conjuring Culture: Ideology and Magic in the Festival of American Folklife", Journat of American Folklore, 104, p. 148-163.

Carpenter, G. (1995), * The Appeal of Fairs, Festivals, and Special Events to Adult Populations $\%$, World Leisure and Recreation, 37 (1), p. 14

Crompton, J. L., and L. L. Love (1995), \& The Predictive Validity of Alternative Approaches to Evaluating Quality of a Festival s, Journal of Travel Research, 34, p. 11-24.
Crompton, J. I, and S. L. McKay (1997), « Motives of Visitors Attending Festival Events $s_{\text {. }}$ Annals of Towism Research, 24 (2), p. 425-439.

Cuba, L. (1989), * From Visitor to Resident: Retiring to Vacationland w, Generations, 13. p. 63-67.

Dawson, D, (1991), \& A Critical Analysis of Ethnic and Multicultural Festivals \&, Journal of Applied Recreation Research, 16 (1), p. 3552.

Farber, C. (1983), * High, Healthy, and Happy: Ontario Mythology on Parade s, in F.E. Manning (Ed.). The Celebration of Society: Perspectives on Contemporary Cultural Performance, Bowling Green, $\mathrm{OH}$, Bowling Green University Popular Press, p. 33-50.

Getz, D. (1991), Festivals, Special Events, and Tourism, New York, Van Nostrand Reinhold.

Getz, D., and W. Frisby (1991), \& Developing a Municipal Policy for Festivals and Special Events *, Recreation Canada, 49, (4), p. 38.

Getz, D., and W. Frisby (1988), \& Evaluating. Measurement Effectiveness in Community-run festivals ", Journal of Travel Research, 27. p. $22-2 \mathrm{~T}$.

Goodrich, J. N. (1978), \& The Relationship Between Preferences for and Perceptions of Vacation Destinations: Application of a Choice Model \$, Journal of Travel Research. 17, p. 813.

Graham, P. (1998), \& Weak Canadian Dollar Likely to Affect Snowbird Economy s, The Record. p. 8.

Hala, J. (1992), \& Fatal Attraction and the Attraction of Fables: A Morphological Analysis $x_{\text {, }}$ Journal of Popular Culture, 26 (3), p. 71-82.

Hitt, H. L. (1954), \& The Role of Migration in Population Change Among the Aged $»$, American Sociological Review, 19, p. 194-200.

Hogan, T., and D. Steinnes (1993), * Elderly Migration to the Sunbelt: Seasonal Vs. Permanent *, Joumal of Applied Gerontology, 12 (2). p. 246-260.

Hoyt, G. C. (1954), * The Life of the Retired in a Trailer Park $\%$, American Joumal of Sociology, 19, p. 361-370.

Jobes, P. (1984), * Old Timers and New Mobile Lifestyles $\%$, Amnats of Tourism Research, 11, p. 181-198.

Jordan, J. W. (1980), * The Summer People and the Natives: Some Effects of Tourism in a Vermont Vacation Village $\cdots$, Annals of Tourism Reseanch, 7 (1), p. 34-55.

Krout, J. A. (1983), * Seasonal Migration of the Elderly n, Gerontologist. 23 (3), p. 295-299. 
Lareau, L. (1983), * Needs Assessments of the Elderly: Conclusions and Methodological Approaches *, Gerontologist, 23, p. 518-526.

Long, P. T., and R. R. Perdue (1990), \& The Economic Impacts of Rural Festivals and Special Events: Assessing the Spatial Distribution of Expenditures *, Journal of Travel Research, 28 (4), p. 10.

Longino, C, and V. Marshall (1990), worth American Research on Seasonal Migration o, Aging and Sociery, 10, p. 229-235.

Marshall, V. W., and C. F. Longino, Jr. (1988), * Older Canadians in Florida: The Social Networks of International Seasonal Migrants *. Comprehensive Gerontology, 2, p. 63-68.

Martin, H. W. S. K. Hoppe, C. L. Larson, and R. L. Leon (1987), a Texas Snowbirds: Seasonal Migrants to the Rio Grande Valley $\%$, Research on Aging, 9 (1), p. 134-147.

Mayfield, T. L., and J. L. Crompton (1995a), \& The Status of the Marketing Concept Among Festival Organizers w, Journal of Travel Research, 34, p. 14-22.

Mayfield, T. L., and J. L. Crompton (1995b), a Development of an Instrument for Identifying Community Reasons for Staging a Festival o, Jourial of Travel Research, 34, p. 37-44.

McClenon, J. (1992), Near-Death Folklore in Medieval China and Japan: A Comparative Analysis *, Asian Folklore Sudies, 50 (2), p. 319-342.

McHugh, K. E., and R. C. Mings (1992), « Canadian Snowbirds in Arizona $\%$, Journal of Applied Recreation Research, 17 (3), p. 255 277.

McHugh, K., and R. Mings (1991), *On the Road Again: Seasonal Migration to a Sunbelt Metropolis *, Urban Geography, 12, p. 1-18.

McHugh, K. E. (1990), * Seasonal Migration as a Substitute For, or Precursor To, Permanent Migration $\%$, Research on Aging, 12 (2), p. 229245 .

McHugh, K. E., and P. Gober (1992), “ ShortTerm Dynamics of the U.S. Interstate Migration System, 1980-1988 \%, Growh and Change, $23(4)$, p. 428-445.

Mings, R. C. (1984), * Recreational Nomads in the Southwestern Sunbelt $\%$, Joumal of Culural Geography, 4, p. 86-99.

Mings, R. C., and K. E. McHugh (1995), a Wintering in the American Sunbelt: Linking Place and Behavior *, The Joumal of Tourism Studies, 6 (2), p- 56-62.

Mings, R. C. and K. E. McHugh (1989), \& The RV Resort Landscape * Journal of Cultural Geography, 10 (1), p. 35-49.
Mullins, L., and R. Tucker (Eds.). (1988), Snowbirds in the Sun Belt: Older Canadians in Florida, Tampa, FL, University of South Florida, International Exchange Center on Gerontology.

Plane, D. A. (1992), Age-Composition Change and the Geographical Dynamics of Interregional Migration in the U.S. $*$, Annals of the Association of American Geographers, 82, p. 64-85,

Ramaprasad, J., and K. Hasegawa (1992), 4. Creative strategies in American and Japanese TV Commercials: A comparison *, Journal of Advertising Research, 32 (1). p. 59-67.

Rodriguez, S. (1998), * Fiesta Time and Plaza Space: Resistance and Accommodation in a Tourist Town w, Joumal of American Folklore, $111(439)$, p. $39-56$.

Rose, L. S., and H. L. Kingma (1989), \& Seasonal Migration of Retired Persons; Estimating its Extent and its Implications for the State of Florida $;$, Journal of Economic and Social Measurement, 15, p. 91-104.

Roseman, C. C. (1983), " A Framework for the Study of Migration Destination Selection $x$, Population and Environment, 6, p. 151-165.

Rothman, R. A. (1978), * Residents and Transients: Community Reaction to Seasonal Visitors $\%$, Journal of Travel Research, 6 (3), p. 813.

Semple. E. C. (1903), American History and its Geographic Condirions, Boston: Houghton Mifflin

Shultis, J. D., M. E. Johnston, and G. D. Twynam (1996), Developing a Longitudinal Research Program to Measure Impacts of a Special Event *, Festival Management and Event Tourism, 4 (1/2), p. 59-66.

St-Onge, T. (1991), Canada's 125th Anniversary: An Example of Public Participation Joumal of Applied Recreation Research, 16(1). p. 53-60.

Stoller, E. P. (1998), * Informal Exchanges With Non-Kin Among Retired Sunbelt Migrants: A Case Study of a Finnish American Retirement Community s, Jowrnal of Gerontology Series $B$-Psychological Sciences and Social Sciences, 54, p. 287-298.

Stoller, E. P. (1989), Ethnicity in the Informal Networks of Older Sunbelt Migrants: A Case History of the Finns in Florida $w_{*}$ Siirtolaisuus-Migration, 16 (1), p. 3-10.

Sullivan, D. A., and S. A. Stevens (1982), « Snowbirds: Seasonal Migrants to the Sunbelt *, Research on Aging, 4 (2), p. 159 . 177.
Timothy, D. J. (1995), * Finnish Settlements in Rural Thunder Bay: Changes in an Ethnic Community w, Sïrolaisus-Migration, $22(1)$, p. 16-24.

Tucker, R. D., V. W. Marshall, C. F. Longino, Jr., and L. C. Mullins (1988), «Older Anglophone Canadian Snowbirds in Florida: A Descriptive Profile $*$, Canadian Journal of Aging, 7, p. 218-232.

Turley, L. W., and S. W. Kelley (1997), \& A Comparison of Advertising Content: Business to Business Versus Consumer Services $\%$, Journal of Advertising, 26 (4), p. 39-48.

van Cleef, E. (1918), * The Finn in American s, Geographical Review, 6, p. $185-214$.

Walle, A. H. (1994), \& Life-Cycle and Tourism Strategies: The Case of the Cowboy Poetry Gathering , Festival Management and Event Tourism, 2 (2), p. 85-94.

Wheelan, $\mathrm{S}_{-}, \mathrm{A}$, and M. Abraham (1993), s The Concept of Intergroup Mirroring: Reality or Illusion? *, Human Relations, 46 (7), p. 803 825.

Wilson, K. L., and W. A. Martin (1982), * Erthnic Enclaves: A Comparison of the Cuban and Black Economies in Miami *, Anerican Journal of Sociology, 88 (1), p. 135-160.

Wiseman, R. F., and C. C. Roseman (1979), * A Typology of Migration Based on the DecisionMaking Process ", Economic Geography, 55 , p. 324-337.

Yangzhou, H., and J. R. B. Ritchie (1993), a Measuring Destination Attractiveness: A Contextual Approach *, Journal of Travel Research, 32 (2), p. 25-34.

Yu, W., and M. D. Van Arsdol, Jr. (1977), a Residential Mobility, Age, and the Life Cycle s, Journal of Gerontology, 32, p. 211 221.

Zeigler, D. J*4 and S. D. Brunn (1985), * $\mathrm{Ur}_{\mathrm{r}}$ ban Ethnic Islands \%, in J. O. McKee (Ed.), Ethicity in Contemporary America: A Geographical Appraisal, Dubuque, Kendall Hunt, p. $259-283$.

Zelinsky, W. (1983), * The Impasse in Migration Theory: A Sketch Map for Potential Escapees *, in P. A. Morrison (Ed.), Population Movements: Their Forms and Funcrions in Urbanization and Develophent, Brussels, International Union for The Scientific Study of Population, p. 19-46. 